\title{
Aikuiskoulutusneuvoston asettamista on kritisoitu
}

Maaliskuussa kääntyivät opetusministeriön puoleen sekä Vapaan sivistystyön yhteisjärjestö että Kansalais- ja työväenopistojen liitto arvostellen aikuiskoulutuksen neuvottelukunnan asettamisen valmistelua ja kokoonpanoa. Lisäksi Kansallinen Kokoomus on tehnyt eduskunnassa opetusministerin vastattavaksi neuvostoa koskevan kirjallisen kyselyn.

Aikuiskoulutusneuvostoa nimitettäessä on korostettu yhteyksiä eduskuntaan sekä työmarkkinajärjestöjen, puolueiden, kunnallisten keskusjärjestöjen ja OAJ:n edustusta. Tärkeä-

\section{Opetusministeriölle}

Vapaan sivistystyön yhteisjärjestö pitää maamme aikuiskasvatuksen kehittämisen kannalta myönteisenä, että väliaikaisen suunnitteluorganisaation työtä jatkamaan on asetettu pysyvä Aikuiskoulutusneuvosto. Tähän periaatteessa hyväksyttävään muutokseen liittyy kuitenkin sellaisia piirteitä, joita Vapaan sivistystyön yhteisjärjestö ei voi hyväksyä. Nykyiseen aikuiskasvatuspoliittiseen tilanteeseen liittyy muitakin ilmiöitä, jotka huolestuttavat yhteisjärjestöä.

Aikuiskoulutusneuvoston perustamisen yhteydessä lakkautettiin Valtion kansansivistyslautakunta. Vaikka Vapaan sivistystyön yhteisjärjestön jäsenjärjestöt edustavat maamme ylivoimaisesti laajinta ja kansainvälisestikin korkeatasoista aikuiskasvatuksen aluetta ja vuosittain yli miljoonaa aikuisopiskelijaa, ovat ne saaneet tyytyä Aikuiskoulutusneuvostossa määrällisesti mitättömän pieneen edustukseen. Neuvoston koostumuksen sivistyspoliittista tasapainottomuutta osoittaa etenkin se, että valtakunnallisesta asemastaan huolimatta kansalais- ja työväenopistot eivät saaneet neuvostoon lainkaan edustajaa. Kokoonpanossa ei ole myöskään riittävästi otettu huomioon parlamentaarisia voimasuhteita. nä pidettiin myös tutkimuksen ja lääninhallituksen edustusta ja valtionhallinnon osuus korostui edelleen kun pysyviksi asiantuntijoiksi kutsuttiin opetushallinnon korkeat virkamiehet.

Asiaa valmisteltaessa on ilmoitettu otetun huomioon aikuiskoulutuksen eri alojen monipuolinen edustus. Alla olevien kannanottojen mukaan eivät maamme merkittävät vapaan sivistystyön järjestöt ole tyytyväisiä edustukseensa aikuiskoulutusneuvostossa.

Ammatillinen perus- ja lisäkoulutus voi parhaimmillaankin vastata vain osaan ihmisen tarpeista, kun sen sijaan vapaa sivistystyö antaa mahdollisuudet koko persoonallisuuden kehittymiselle ja erityisesti ihmiskuvan, yhteiskuntakäsityksen ja maailmankatsomuksen avartamiselle. Hyvin toimiva vapaan sivistystyön järjestelmä palvelee myös työelämän tarpeita, sillä uusiutuvan teknologian aikana muutoinkin nopeasti muuttuvassa maailmassa tarvitaan henkisesti joustavaa, oppimiskykyistä ja laaja-alaista aikuista. Vapaa sivistystyö kykenee tarjoamaan ammatillisesti välttämätöntä yleissivistystä sen lisäksi, että se aktivoi kansalaisia yhteiskunnalliseen ja kultturelliseen toimintaan. Sen tähden vapaata sivistystyötä koskevia lainsäädännöllisiä uudistuksia ei saa lykätä.

Aikuiskoulutuksen kehittämisorganisaatiossa on usean vuoden ajan työskennellyt toimikuntia, jotka ovat perusteellisesti pohtineet koulutuksen uudistamista. Toimikunnat ovat tehneet joukon toimenpide-esityksiä, jotka ovat saaneet laajalti tukea ja kannatusta. Jotta aikuiskasvatuksen mahdollisuudet yhteiskunnallisessa kehittämistyössä tulisivat täysimääräisesti hyväksikäytetyksi, Järjestöllisen sivistystyön toimikunnan (komiteanmietintö 1983:40), Kunnallisen aikuiskoulutuksen toi- 
mikunnan (komiteanmietintö 1984:10) ja Aikuisten opintososiaalisen toimikunnan (komiteanmietintö 1983:48) mietinnöissä esitettyjen ehdotusten perustalta lähtevä uudistamistyö on välittömästi aloitettava.

Edellä esitetyn perusteella Vapaan sivistyön yhteisjärjestö esittää, että

1) Aikuiskoulutusneuvostoa laajennetaan edustamaan tasapuolisemmin aikuiskasvatuksen eri alueita ja yhteiskunnallisia näkemyksiä sekä perustetaan sen osaksi vapaan sivistystyön jaosto,

2) säädetään laki sivistysjärjestöjen valtion- avusta Järjestöllisen sivistystyön toimikunnan esitysten pohjalta,

3) ryhdytään Kunnallisen aikuiskoulutuksen toimikunnan ehdottamiin toimenpiteisiin sekä

4) toteutetaan aikuisten opintososiaalisen järjestelmän uudistus asiaa selvittäneen toimikunnan esitysten pohjalta.

Helsingissä 1. maaliskuuta 1985

Vapaan sivistystyön yhteisjärjestö

Oili Parjo

Helena Kekkonen

puheenjohtaja pääsihteeri

\section{Opetusministeri Kaarina Suonio}

\section{Helsingissä 16.3.1985 kokoontunut} Kansalais- ja työväenopistojen liiton valtuusto toteaa seuraavaa:

Maamme aikuiskasvatuksen järjestelmää on uudistettu viidentoista vuoden ajan. Tavoitteena on ollut kokonaisjärjestelmä, joka sulauttaa itseensä niin ammatillisen ja kouluopintoja täydentävän yleissivistävän aikuiskoulutuksen kuin vapaan sivistystyönkin. Ongelmallisinta aikuiskoulutuksen järjestelmään on kuitenkin ollut niveltää vapaa sivistystyö, koska se poikkeaa toimintaperiaatteiltaan muusta aikuiskasvatuksesta.

\section{Aikuiskoulutuksen nykyvaihe}

Kehittämistyö on kulminoitunut valtioneuvoston 18.10.1984 tekemään päätökseen aikuiskoulutusneuvostosta ja asettamiseen 27.12.1984. Kolmivuotiskaudeksi 1.1.1985 31.12.1987 asetetusta neuvostosta puuttuu vapaan sivistystyön suora edustus. Kansalaisja työväenopistoilla suurimpana vapaan sivistystyön lohkona ei ole välillistäkään edustusta neuvoston kokoonpanossa. Asian esittelyn perusteluissa vapaata sivistystyötä ei mainita sanallakaan.

Aikuiskoulutusneuvoston asettaminen on aikuiskoulutuksen kehittämisen kannalta sinänsä myönteinen asia, jonka kuitenkin mutkistaa samanaikaisesti tapahtunut valtion kansansivistyslautakunnan lakkauttaminen. Asiallisesti lautakunnan tehtävät siirtyvät elimelle, jossa vapaan sivistystyön virallista mukanaoloa ei ole huomioitu siitä huolimatta, että sen piirissä opiskelee vuosittain kaikkiaan yli miljoona aikuista.

\section{Vapaata sivistystyötä syrjitty}

Kansalais- ja työväenopistojen liiton valtuusto ei voi hyväksyä tapaa, jolla aikuiskoulutusneuvoston asettamista on valmisteltu. Missään vaiheessa liiton päättäviltä elimiltä ei ole tiedusteltu kantaa neuvoston asettamiseen, kokoonpanon perusteisiin puhumattakaan esityksistä neuvoston jäseniksi. Mielipidettä ei liioin ole kysytty kansansivistyslautakunnan lakkautuspäätöksen yhteydessä.

Valtuusto toteaa, että myöskään eduskunnassa ei ole täysin tyytyväisiä neuvoston asettamistapaan, jota koskeva kirjallinen kysely on jätetty 5.3.1985 asianomaisen valtioneuvoston jäsenen vastattavaksi. Aikuiskoulutusneuvoston kokoonpanoa koskevassa kyselyssä esitetään huolestuminen myös vapaan sivistystyön alimitoitetusta edustuksesta ja kansalais- ja työväenopistojen edustuksen puuttumisesta kokonaan.

\section{Oma edunvalvontaelin vapaalle sivistystyölle}

Tässä tilanteessa 600000 aikuisopiskelijaa edustava Kansalais- ja työväenopistojen liitto: 
- vaatii vapaan sivistystyön organisaatioiden edustajista kokoonpannun edunvalvontaelimen perustamista valtionhallintoon

- esittää, että ryhdytään välittömästi toimenpiteisiin vapaan sivistystyön edunvalvonnan turvaamiseksi valtionhallinnossa tavalla, joka tyydyttää kaikkia vapaan sivistystyön organisaatioita

- esittää, että vapaata sivistystyötä koskevien lausuntojen antaminen, kuten määrärahojen jakamisperusteet, määritetään omaksi tehtäväkokonaisuudeksi toistaiseksi ope- tusministeriön vastuulle.

Kansalais- ja työväenopistojen liiton valtuusto tähdentää vapaan sivistystyön autonomiaan nojaavaa sivistyspoliittista linjaa, jonka pohjalta vapaan sivistystyön ja opistoliikkeen arvostus säilyy myös tulevina vuosina.

16. maaliskuuta 1985 Helsingissä

Kansalais- ja työväenopistojen liitto Valtuusto

Paula Tuomikoski

Valtuuston puheenjohtaja

\section{Eduskuntakysymys...}

Valtioneuvosto antoi päätöksen aikuiskoulutusneuvostosta 18 päivänä lokakuuta 1984 . Sanotun päätöksen $3 \S$ kuuluu seuraavasti: "Aikuiskoulutusneuvostoon kuuluu puheenjohtaja ja enintään kaksitoista muuta jäsentä sekä yhtä monta henkilökohtaista varajäsentä, joiden tulee edustaa monipuolisesti aikuiskoulutuksen eri alueita ja erilaisia yhteiskuntanäkemyksiä sekä maan molempia kieliryhmiä.",

Valtioneuvoston päätöksellä 27.12. 1984 asetettiin aikuiskoulutusneuvosto kolmivuotiskaudeksi 1.1.1985-31.12. 1987. Valtioneuvoston suorittama nimityspäätös on jyrkässä ristiriidassa edellä mainitun valtioneuvoston periaatepäätöksen kanssa. Opetusministeriö ei ole esittelyssään ottanut huomioon erilaisten yhteiskuntanäkemysten tasapuolista esilletuomista ja vapaan sivistystyön osuus aikuiskoulutusneuvostossa on selvästi alimitoitettu.

Osoituksena opetusministeriön yksipuolisesta nimitysvalmistelusta on se, että maamme toiseksi suurimmalle puolueelle - Kansallisella Kokoomuksella - ei ole yhtään varsinaista jäsentä aikuiskoulutusneuvostossa. Esityksen valmistelussa ei ole näin ollen huomioitu "erilaisten yhteiskuntanäkemysten monipuolista edustusta", kuten valtioneuvoston päätöksessä edellytetään.

Opetusministeriön sosialidemokraattisen osastopäällikön Leevi Melametsän esittelymuistiossa todetaan: "Oppositiopuolueiden osalta ehdokkaita pyydettiin Kansallisen Kokoomuksen ja SKDL:n puoluetoimistoista. Kaikki mukana olleet puoluetahot ovat ilmaisseet suostumuksensa ehdotettuun kokoonpanoon omalta osaltaan." Osastopäällikkö Me- lametsän muistio aikuiskoulutusneuvoston esittelykokoonpanosta vastannee tosiasiassa enemmän muita mieltymyksiä kuin Kansallinen Kokoomus r.p.:n virallisia käsityksiä.

Esittelymuistiossa tuotiin esille aikuiskoulutuksen suuri koulutuspoliittinen merkitys. Aikuiskoulutusneuvoston pysyviksi asiantuntijoiksi ehdotettiin tällä perusteella kahta vasemmistolaista ja yhtä keskustaan lukeutuvaa henkilöä. Tasapuolisuus ei toteutunut neuvostossa tältäkään osin. Pikemminkin voidaan puhua suoranaisesta poliittisesta diskriminaatiosta.

Erilaisten yhteiskuntanäkemysten monipuolisen esilletulon ehkäisyn lisäksi vapaan sivistystyön osuus aikuiskoulutusneuvostossa on selvästikin riittämätön. Vapaan Sivistystyön Yhteisjärjestö jäsenineen edustaa maan laajinta aikuiskasvatussektoria. Tämän keskeisen lohkon näkemyksiä selvästikin aliarvioidaan. Neuvoston sivistyspoliittista tasapainottomuutta korostaa vielä sekin, että varsinaiset kansalais- ja työväenopistot eivät ole saaneet lainkaan edustajaansa neuvostoon.

Edellä olevan perusteella ja valtiopäiväjärjestyksen $37 \S$ :n 1 momenttiin viitaten esitämme kunnioittavasti valtioneuvoston asianomaisen jäsenen vastattavaksi seuraavan kysymyksen:

Mihin toimenpiteisiin Hallitus aikoo ryhtyä, jotta aikuiskoulutusneuvoston kokoonpano vastaisi valtioneuvoston päätöksessä 18 päivältä lokakuuta 1984 määritettyjä periaatteita?

Helsingissä 5 päivänä maaliskuuta 1985 Aino Pohjanoksa ym. 


\section{...ministerin vastaus}

Valtiopäiväjärjestyksen 37 §:n 1 momentissa mainitussa tarkoituksessa Te, Herra Puhemies, olette 5 päivänä maaliskuuta 1985 päivätyn kirjeenne ohella toimittanut valtioneuvoston asianomaiselle jäsenelle jäljennöksen kansanedustaja Pohjanoksan ym. kirjallisesta kysymyksestä n:o 79:

Mihin toimenpiteisiin Hallitus aikoo ryhtyä, jotta aikuiskoulutusneuvoston kokoonpano vastaisi valtioneuvoston päätöksessä 18 päivältä lokakuuta 1984 määritettyjä periaatteita?

Vastauksena kysymykseen esitän kunnioittaen seuraavaa:

Valtioneuvoston aikuiskoulutusneuvostosta tekemässä päätöksessä todetaan neuvoston kokoonpanosta seuraavaa: "Aikuiskoulutusneuvostoon kuuluu puheenjohtaja ja enintään kaksitoista muuta jäsentä sekä yhtä monta henkilökohtaista varajäsentä, joiden tulee edustaa monipuolisesti aikuiskoulutuksen eri alueita ja erilaisia yhteiskuntanäkemyksiä sekä maan molempia kieliryhmiä."

Mainitulla valtioneuvoston päätöksellä lakkautettiin kolme opetusministeriön apuna toiminutta asiantuntijaelintä, nimittäin valtion kansansivistyslautakunta, aikuiskoulutuksen neuvottelukunta ja aikuiskoulutuksen johtoryhmä.

Kun näin yhdellä 13-jäsenisellä aikuiskoulutusneuvostolla tavallaan korvattiin kolme asiantuntijaelintä, joissa oli yhteensä 41 varsinaista jäsentä, on luonnollista, että moni talo, joka oli mukana aikaisemmissa asiantuntijaelimissä, jouduttiin jättämään nyt pois. Jäseniä valittaessa aikuiskoulutusneuvostoon pyrittiinkin löytämään henkilöitä, joissa yhtyy mahdollisimman monipuolinen asiantuntemus.

Tehdessään päätöksen aikuiskoulutuksen suunnittelun ja kehittämisen periaatteista vuonna 1978 valtioneuvosto painotti ensisijaisesti ammatillisen aikuiskoulutuksen kehittämistä. Tämän painotuksen tulisi näkyä myös aikuiskoulutusneuvoston kokoonpanossa. Kuitenkin sen kolmestatoista varsinaisesta jäsenestä viisi on joko vapaan sivistystyön järjestöjen työntekijöitä tai vastuunalaisissa luottamustehtävissä sanotuissa järjestöissä. Lisäksi muista jäsenistä ainakin kolme on aikaisemmin toiminut vapaan sivistystyön työntekijöinä ja yksi hoitaa vapaan sivistystyön hallintotehtäviä lääninhallituksessa. Varajäsenten joukossa on niin ikään vapaan sivistystyön asiantuntemusta.

Kysymyksessä esitettyä väitettä vapaan sivis- tystyön edustuksen selvästä riittämättömyydestä tai aliarvioimisesta ei edellä esitetyn perusteella voi pitää aiheellisena. Lisäksi vapaan sivistystyön asiantuntemus on pyritty ottamaan huomioon aikuiskoulutusneuvoston sihteeristössä.

Kysymyksessä väitetään myös, että aikuiskoulutusneuvoston nimittämisessä ei ole otettu huomioon valtioneuvoston päätöksessä mainittua edellytystä, että jäsenten ja varajäsenten tulee edustaa erilaisia yhteiskuntanäkemyksiä.

Aikuiskoulutusneuvostoa koottaessa pyrittiin siihen ensisijaisesti saamaan mahdollisimman monipuolinen aikuiskoulutuksen edustus. Erilaisten yhteiskuntanäkemysten takaamiseksi pyrittiin mukaan saamaan mm. työntekijäja työnantajajärjestöjen, kaupunki- ja maaseutukuntien sekä eri hallintotasojen edustus. Samaten pyrittiin mahdollisuuksien mukaan saamaan mukaan eri puolueiden näkemyksiä, vaikka puoluekantaa ei läheskään kaikkien jäsenten osalta katsottu mahdolliseksi tai tarpeelliseksi selvittää. Tiettävästi kuitenkin esim. kysymyksessä mainittu Kansallinen Kokoomus r.p. on mukana ainakin neuvoston varajäsenen ja samalla erään jaoston varsinaisen jäsenen ominaisuudessa. Kysymyksessä kiinnitetään huomiota lopullisen päätöksen ja perustelumuistion väliseen ristiriitaan. Havainto on oikea. Perustelumuistio oli laadittu päätösehdotukseen, jossa neuvoston kokoonpanolla oli "puoluetahojen suostumus" omalta osaltaan. Tämä esitys ei kuitenkaan tullut valtioneuvostossa hyväksytyksi, koska mm. valtioneuvoston päätöksessä nimenomaisesti edellytetty maan molempien kieliryhmien edustus ei riittävästi toteutunut. Niinpä esitystä muutettiin ja se tuotiin valtioneuvoston ylimääräiseen esittelyyn, jossa uusi ehdotus yksimielisesti hyväksyttiin. Esittelymuistiota ei tässä yhteydessä huomattu korjata eikä sillä olisi ollut merkitystä päätöksen sisältöön nähden.

Kysymyksessä esitetään "poliittisesta diskriminaatiosta" esimerkkinä pysyvien asiantuntijoiden valinta. Pysyvät asiantuntijat ovat opetusministeriön suunnittelupäällikkö sekä molempien opetusministeriön alaisten keskusvirastojen pääjohtajat. Heidän osaltaan ei luonnollisestikaan valintaan vaikuttanut heidän mahdollinen poliittinen kantansa.

Edellä esitettyyn viitaten voidaan katsoa, että aikuiskoulutusneuvoston kokoonpanossa on otettu huomioon ne periaatteet, joita valtioneuvosto päätöksessään aikuiskoulutusneuvostosta edellytti. Tarvittaessa neuvosto voi komiteasäännösten mukaisesti kuulla asiantuntijoita riittävän monipuolisen kuvan luomi- 
seksi käsiteltävistä asioista.

Näin ollen, ja koska opetusministeriön toisenlaisesta yrityksestä huolimatta, aikuiskoulutusneuvosto jäi suhteellisen pieneksi kooltaan, ei hallitus aio ryhtyä neuvoston jäsenten ja varajäsenten kokoonpanon muuttamiseen alkaneen kolmivuotiskauden aikana.

Helsingissä 10 päivänä huhtikuuta 1985 Opetusministeri Kaarina Suonio

\section{Aikuiskoulutus- neuvoston sihteerit}

Aloittaessaan työtään on aikuiskoulutusneuvosto valinnut seuraavat henkilöt sihteereikseen:

- koko neuvosto; nuorempi hallitussihteeri Marja-Riitta Pönkä opetusministeriöstä

- työjaosto; toiminnanjohtaja Timo Toiviainen Kansalais- ja työväenopistojen liitosta

- yleissivistävän aikuiskoulutuksen jaosto; toimittaja Jaani Viherluoto Yleisradiosta

- ammatillisen aikuiskoulutuksen jaosto; vt. ylitarkastaja Hannu Sirén opetusministeriöstä

- ruotsinkielisen aikuiskoulutuksen jaosto; rehtori Clas-Åke Storå, Pedersöre medborgarinstitutista

Lisäksi neuvosto on kutsunut pysyväksi asiantuntijaksi apulaistoiminnanjohtaja Risto Kuosmasen Kansalais- ja työväenopistojen liitosta. 